\title{
Enzymatic Kinetics of Enzymatically Extruded Degerminated Maize Using Glucamylase
}

\author{
Chengye $\mathrm{Ma}^{1,2}$, Shuangshuang $\mathrm{Yu}^{1}$, Yuyan $\mathrm{Fan}^{1}$, Shuhua $\mathrm{Wu}^{1}$, Zhehao Zhang ${ }^{1}$, Yuedong Song ${ }^{1} \&$ Hongjun $\mathrm{Li}^{1,2}$ \\ ${ }^{1}$ School of Agricultural Engineering and Food Science, Shandong University of Technology, Zibo, 255000, \\ China \\ ${ }^{2}$ Key Laboratory of Shandong Provincial Universities for Technologies in Functional Agricultural Products, Zibo, \\ 255000, China \\ Correspondence: Chengye Ma, School of Agricultural Engineering and Food Science, Shandong University of \\ Technology, Zibo, China. E-mail: mcycn2002@163.com
}

Received: November 18, 2017 Accepted: December 8, $2017 \quad$ Online Published: January 23, 2018

doi:10.5539/jfr.v7n2p10 URL: https://doi.org/10.5539/jfr.v7n2p10

\begin{abstract}
In this study, the reaction rates of native degerminated maize, extruded degerminated maize and enzymatically extruded degerminated maize using glucoamylase were evaluated and the extrudate models were investigated. The effects of enzyme concentration, substrate $\mathrm{pH}$, temperature and incubation time on the reaction rates were studied. The Lineweaver-Burk equation was used in order to obtain the parameters of the kinetics equation of catalysed hydrolysis. The results show that NDM's vm is $0.0845 \mathrm{~g} /(\mathrm{mL} \cdot \mathrm{min})$ and $\mathrm{km}$ is 0.0032 , EDM's vm is $0.6251 \mathrm{~g} /(\mathrm{mL} \cdot \mathrm{min})$ and $\mathrm{km}$ is 0.0167 , EEDM's vm is $1.897 \mathrm{~g} /(\mathrm{mL} \cdot \mathrm{min})$ and $\mathrm{km}$ is 0.0240 . The reaction rate of EEDM is quicker than those of NDM and EDM. The kinetics equation of EEDM is in accordance with the Michaelis-Menten equation.
\end{abstract}

Keywords: extrusion, degerminated maize, glucoamylase, enzymatic kinetics

\section{Introduction}

Maize is a major grain crop rich in linoleic acid, minerals and vitamins, and has a high nutritional and medicinal value. Maize has been used in many processing sectors including food processing, feed processing and deep processing, and starch syrup is a very important component of deep processing. Starch produced using the wet method of degerminated maize compared with using the dry method has many advantages, including reducing the equipment investment cost, shortening the process flow, and reducing sewage discharge and energy consumption. The combined application of extrusion and enzymatic technology is an effective method of biological and mechanical degradation, accelerating the rate of hydrolysis of amylase and improving the utilization rate of starch (Shen et al. 2010).

Enzymatic kinetics can be described as a science based on enzyme catalysis and the factors which affect it (Román et al. 2016). The parameters and equation of enzymatics kinetics can be obtained by analysing different actors such as substrate concentrations, and varying the $\mathrm{pH}$, temperature and reaction time (Baks et al. 2008; Raphaelides et al. 2012). Literature regarding enzymatic kinetics has been reported (Stephen and Wang 2009) and an enzymatic kinetics model has been built by analysing the influence of the above-mentioned parameters(Gao et al. 2017). The parameters and equation of enzymatic kinetics of maize starch have been obtained by analysing the effects of different concentrations of enzymes, and varying the $\mathrm{pH}$, temperature and time ofthereaction rate of $\beta$-amylase (Zhao et al. 2009).

Extrusion technology is a process involving transporting, mixing, smashing, shearing and pumping, which has the advantages of energy saving and enabling high quality and yield (Morales et al. 2015). Enzyme technology combined with extrusion activation is an effective method of the biological and mechanical degradation of starch, accelerating the reaction rate of amylase and increasing the ratio of starch. During the extrusion process, the effect of moisture, heat and mechanical shear ruptures hydrogen bonds, the crystalline structure and starch grains; hence, the enzymatic kinetics equation of extrudates needs to be investigated.

The aim of this study was to compare the reaction rate of enzymatically extruded degerminated maize with degerminated maize and extruded degerminated maize, and to build an enzymatic kinetics model using the 
Lineweaver-Burk method, as the rules and a model of enzymatic kinetics can provide support for the production of starch syrup.

\section{Material and Methods}

\subsection{Materials}

The raw material used in this study was degerminated maize with a $12.58 \%$ moisture content, $74.46 \%$ starch content, $7.96 \%$ protein content and $0.96 \%$ fat content, which was purchased from Tianjin Food Co., LTD. Glucoamylase, 20000u/g, was purchased from Beijing AoBoXing Biological Technology Co., LTD. Thermostable $\alpha$-amylase, $40000 \mathrm{u} / \mathrm{mL}$, was purchased from Shandong LongDa Biological Engineering co., Ltd. All other chemicals used were of analytical grade.

\subsection{Instruments and Equipment}

Figure 1 is the single-screw extruder .It was made by Shandong University of Technology, which consisted of a modular barrel (three pieces) and screw (four pieces), with a productivity of $100 \mathrm{~kg} / \mathrm{h}$. The screw rotation speed varies from 0 to $1200 \mathrm{rpm}$, the barrel is continuously adjustable at a temperature range between $0 \sim 300^{\circ} \mathrm{C}$ and the extruder is equipped with an automatically controlled closed-loop digital instrumentation system. The die diameter of the extruder and clearance between the templates and screw top are adjustable.

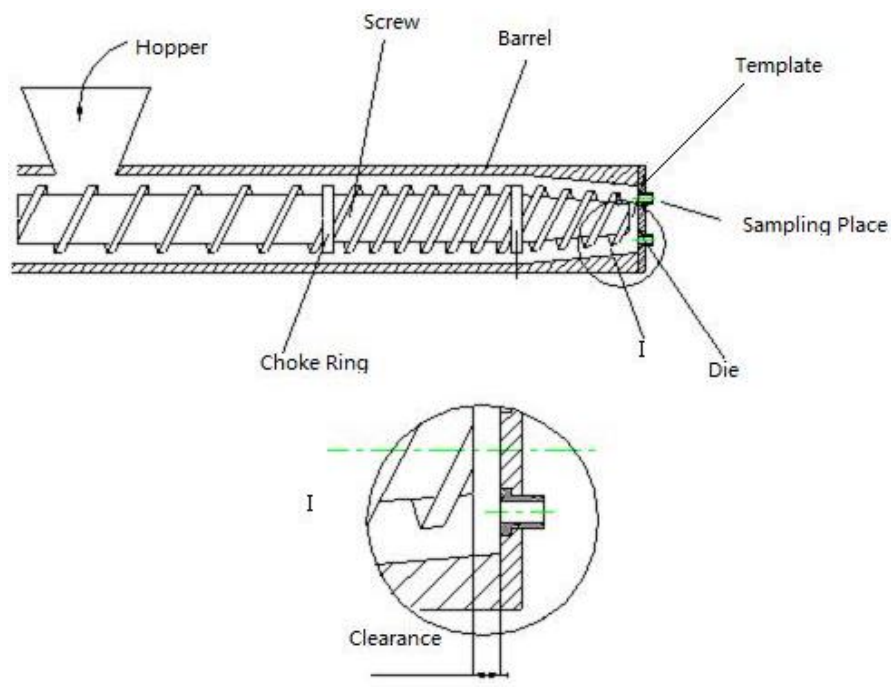

Figure 1. Schematic diagram of single-screw extruder

A UV-2102PCS ultraviolet and visible spectrophotometer (Ke Instrument Co., LTD, Shanghai, China) was used for analysis.

\subsection{Preparation of Enzymatically Extruded Degerminated Maize}

Degerminated maize with a moisture content was $30.0 \%$ was ground to flour and thermos tablea-amylase was added. The system parameters of the single-screw extruder are shown in Table 1.

\subsection{Preparation of Liquid Glucose and Determination of Reducing Sugar Content}

$6.00 \mathrm{~g}$ samples were added to $38.0 \mathrm{~mL}$ acetic acid-sodium acetate buffer in tubes. After 10 minutes in a water bath at $55{ }^{\circ} \mathrm{C}$, a specific amount of glucoamylase was added and the solution was left in the water bath at $55^{\circ} \mathrm{C}$ for $30 \mathrm{~min}$. The reaction was stopped by increasing the water bath temperature to $100^{\circ} \mathrm{C}$ for $10 \mathrm{~min}$. Finally, the solution was centrifuged at $4000 \mathrm{rpm}$ for $20 \mathrm{~min}$ to separate the liquid supernatant from the reaction slurry.

The consumption volume of the sugar solution was measured and the reducing sugar concentration was determined on the basis of direct titration of GB/T5009.7-2008(Chinese national standards). 
Table 1. System parameters of the single extruder

\begin{tabular}{|c|c|c|c|c|c|c|c|}
\hline No. & & $\begin{array}{l}\text { Diameter of die } \\
\text { nozzle/amount } \\
\mathrm{mm}\end{array}$ & $\begin{array}{l}\text { Temperature } \\
\text { at end of } \\
\text { discharge } \\
{ }^{\circ} \mathrm{C}\end{array}$ & $\begin{array}{l}\text { Speed } \\
\text { of } \\
\text { screw } \\
\text { r/min }\end{array}$ & $\begin{array}{l}\text { Moisture } \\
\text { content } \\
\%\end{array}$ & $\begin{array}{l}\text { Thermostable } \\
\alpha \text {-amylase } \\
\text { contentu/g }\end{array}$ & Remarks \\
\hline 1 & $\begin{array}{l}\text { Native } \\
\text { degerminated } \\
\text { maize }\end{array}$ & 1 & I & I & I & I & NDM \\
\hline 2 & $\begin{array}{l}\text { Extruded } \\
\text { degerminated } \\
\text { maize }\end{array}$ & $\varphi 12 \times 3$ & 60.0 & 110.0 & 30.0 & 0 & EDM \\
\hline 3 & $\begin{array}{l}\text { Enzymatically } \\
\text { extruded } \\
\text { degerminated } \\
\text { maize }\end{array}$ & $\varphi 12 \times 3$ & 60.0 & 110.0 & 30.0 & 10.0 & EEDM \\
\hline
\end{tabular}

\subsection{The Measurement of the Kinetics}

Constant Enzymatic Kinetics was Analysed Using the Michaelis-MentenEquation and the Parameters of Kinetics were Obtained Using Double-Reciprocal Analysis(BP et al. 2006). Different concentrations of the three samples were taken and the reaction rates were measured. The Michaelis-Menten equation is shown below.

$$
v=\frac{v_{\max }[s]}{k_{m}+[s]}
$$

The reciprocal of the Michaelis-Menten equation is:

$$
\frac{1}{v}=\frac{k_{m}+k_{m}[s]}{v_{\max }[s]}
$$

The reaction rate was calculated and the reciprocal of the Michaelis-Menten equation was obtained.

\subsection{Statistical Analysis All Experiments were Performedin Triplicate and Data are Expressed as Means}

Statistical analysis was performed using SAS9.1, and comparisons between the reaction rate and time were performed using ANOVA; statistical significance was considered as $\mathrm{p}<0.05$. The figures were processed by origin8.0 and Vmax and Km were calculated according to the Lineweaver-Burk plot.

\section{Results and Discussion}

\subsection{The Solution of the Michaelis Constant and the Maximal Reaction Rate}

The Lineweaver-Burk equation was used to determine the kinetic parameters and the plots obtained are presented in Fig. 2; the least square method was used to perform linear fitting(Jukić et al. 2007). The results show a linear relationship between $1 / \mathrm{S}$ and $1 / \mathrm{V}$ in the control, and the correlation coefficients of equations were above 0.9500 and equations were highly significant. 


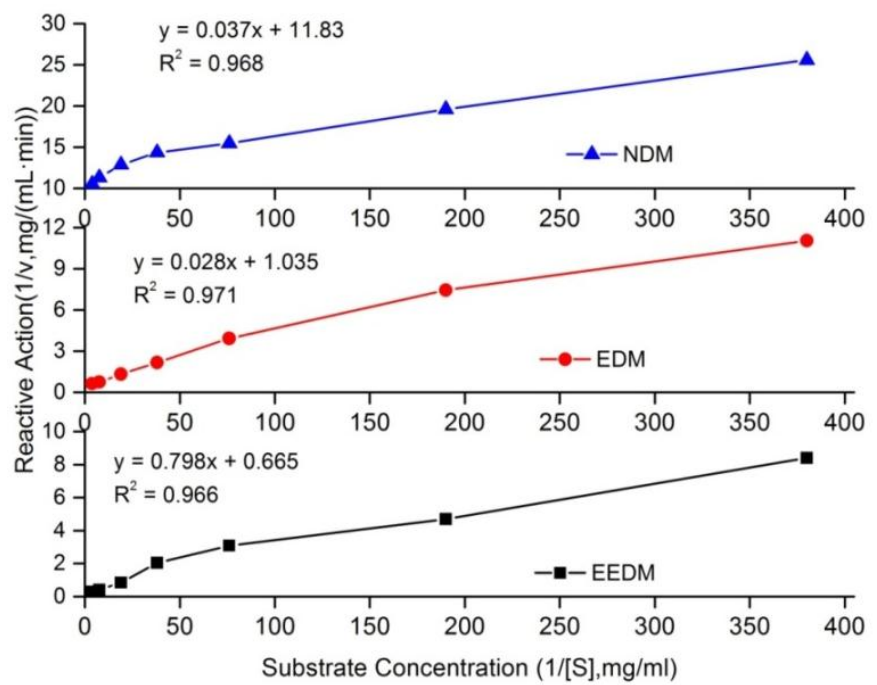

Figure 2. Lineweaver-Burk plot for the glucoamylase catalysed hydrolysis of enzymatically extruded degermed maize

The equation, coefficient of association, Vmax and $\mathrm{Km}$ are shown in Table 2. It can be seen that $\mathrm{R} 2$ is above 0.96 and there action rules of all three materials follow the Lineweaver-Burk equation and exhibited good correlation. A higher $\mathrm{Km}$ value indicates higher affinity and according to the value of Km, EEDM had the strongest affinity with glucoamylase and NDM had a lower affinity than the two other materials used. Enzymatic extrusion can make degerminated maize gelatinized and decrease the degree of polymerization; however, the contact area of degerminated maize and glucoamylase was increased. The advantages of using the Lineweaver-Burk graph method is that it is convenient and fast (Baks et al. 2006b), and the results are accurate. This method is governed by substrate concentration as a low concentration of substrate resulted in a low enzymatic hydrolysis rate and influenced the accurate measurements of Vmax and $\mathrm{Km}$. Generally, the result was accurate when the substrate concentration was 0 to $10 \mathrm{mg} / \mathrm{mL}$ or from 0.33 to $2.0 \mathrm{Km}$ (Zhang et al. 2007).

Table2.Kinetics Equation of Catalysed Hydrolysis Using the Lineweaver-Burk Plot

\begin{tabular}{llllll}
\hline No. & Samples & Equations & $\mathrm{R}^{2}$ & $\mathrm{~V}_{\max } \mathrm{mg} /(\mathrm{mL} \cdot \mathrm{min})$ & $\mathrm{K}_{\mathrm{m}}(\mathrm{mg} / \mathrm{mL})$ \\
\hline 1 & Degerminated maize & $y_{1}=0.0327 x_{1}+10.4530$ & 0.9680 & 0.0845 & 0.0032 \\
2 & Extruded degerminated maize & $y_{2}=0.0202 x_{2}+0.8406$ & 0.9768 & 0.6251 & 0.0167 \\
3 & $\begin{array}{l}\text { Enzymaticallyextruded } \\
\text { degerminated maize }\end{array}$ & $y_{3}=0.7980 x_{3}+0.7750$ & 0.9660 & 1.1897 & 0.0240 \\
\hline
\end{tabular}

\subsection{Effect of the Enzyme Concentration of Feed Materials on Reaction Rate}

As shown in Fig. 3, the reaction rates increased with an increase in enzyme concentration. Under the conditions of sufficient substrate, higher enzyme concentrations exhibited faster reaction rates, resulting in more product. This was ascribed to the fact that the increased enzyme concentration provides more active sites, increasing the probability of an enzyme-substrate collision and subsequent reaction, leading to a higher reaction rate (Raphaelides et al. 2012).The reaction rate of NDM increased slowly upon increasing the enzyme concentration, while EEDM increased the quickest. Without squeezing, degerminated maize kept its original crystalline structure and was not easy to hydrolyse; however, extrusion gelatinized the degerminated maize and destroyed the crystalline texture, which led to an accelerated rate of hydrolysis (Zhang et al. 2015). On this basis, glucoamylase hydrolysed the $\alpha-1,4$ glycosidic and $\alpha-1,6$ glycosidic linkages, which led to maize producing glucose molecules exhibiting a low degree of polymerization; hence, the reaction rate of EEDM was the fastest (Han 2009). Under the conditions of unchanged temperature and $\mathrm{pH}$ and sufficient substrate concentration, the higher the enzyme concentration was, the faster the reaction rate (Zhao et al. 2009). 


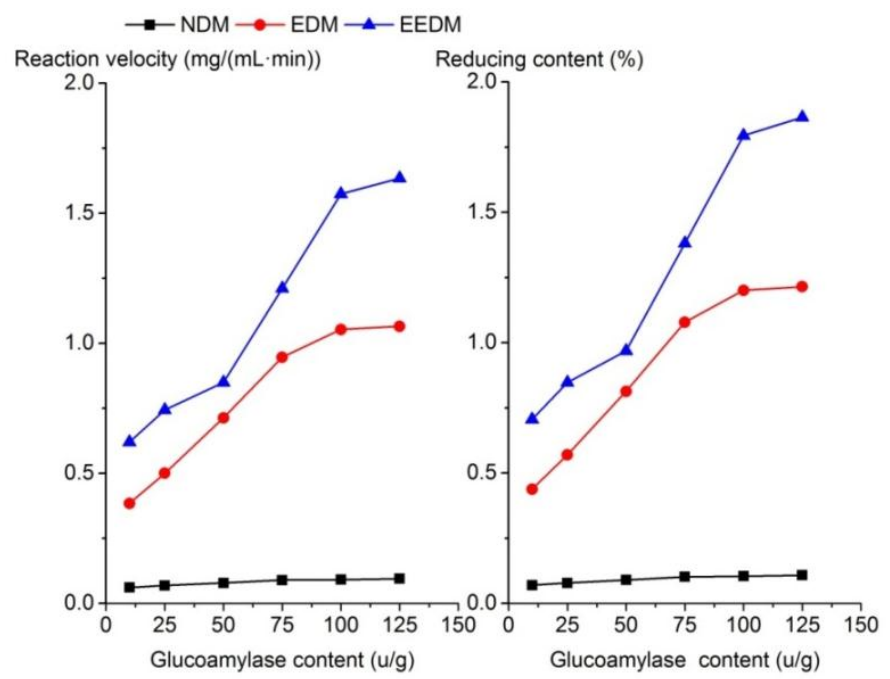

Figure 3. The effects of different substrate enzyme concentrations on reaction rates

\subsection{Effect of Temperature on the Reaction Rate}

As observed in Fig. 4, the optimum reaction temperature for NDM was $40^{\circ} \mathrm{C}$. For the other two materials, the optimum reaction temperature was $50^{\circ} \mathrm{C}$. Enzyme activity was enhanced upon increasing the temperature over a range of temperatures; however, when the reaction temperature increased up to $50^{\circ} \mathrm{C}$, the reaction rate was lower, due to the fact that high temperatures can prevent gelatinization and lower enzyme activity. Studying the enzymatic kinetics of $\alpha$-amylase during the saccharification process shows the degree of hydrolysis increased upon increasing the temperature, whereas the enzyme activity decreased; $60^{\circ} \mathrm{C}$ was found to be a good temperature for both the degree of hydrolysis and enzyme activity (Baks et al. 2006a).

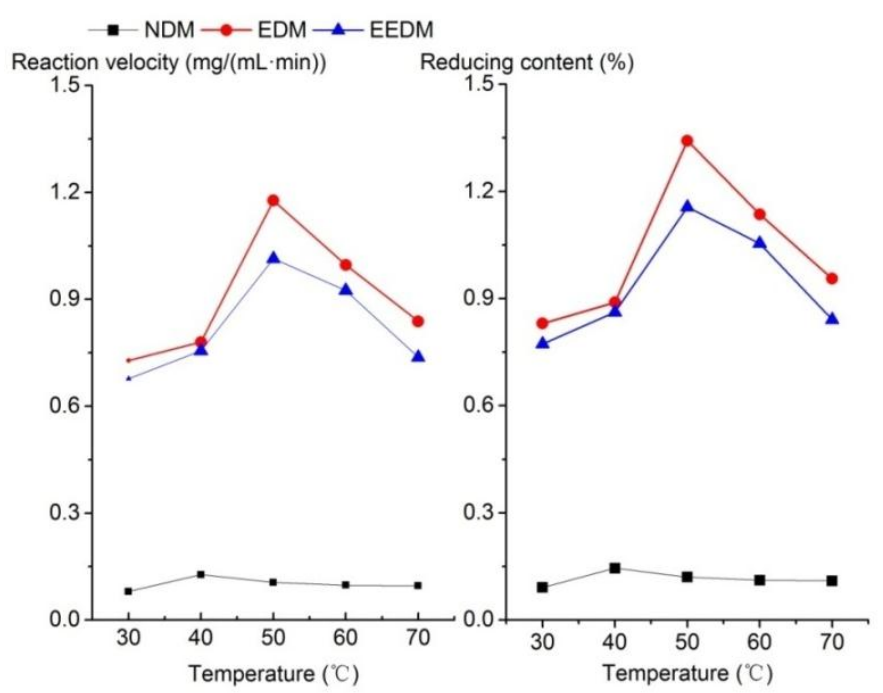

Figure 4. The effects of temperature on reaction rates

\subsection{Effect of Reaction Time on Reaction Rate}

Figure 5 shows the reaction rate over the reaction time. The initial hydrolysis reaction rate, at the same concentration levels, was highest in EEDM, followed by EDM, and lastly NDM. As the reaction process progressed, the reaction rate gradually slowed down, with the fifth reaction rate of three materials being the fastest. The reaction rate was slowed down by the decrease of raw material concentration and increasing time (Polakovič and Bryjak 2004). 


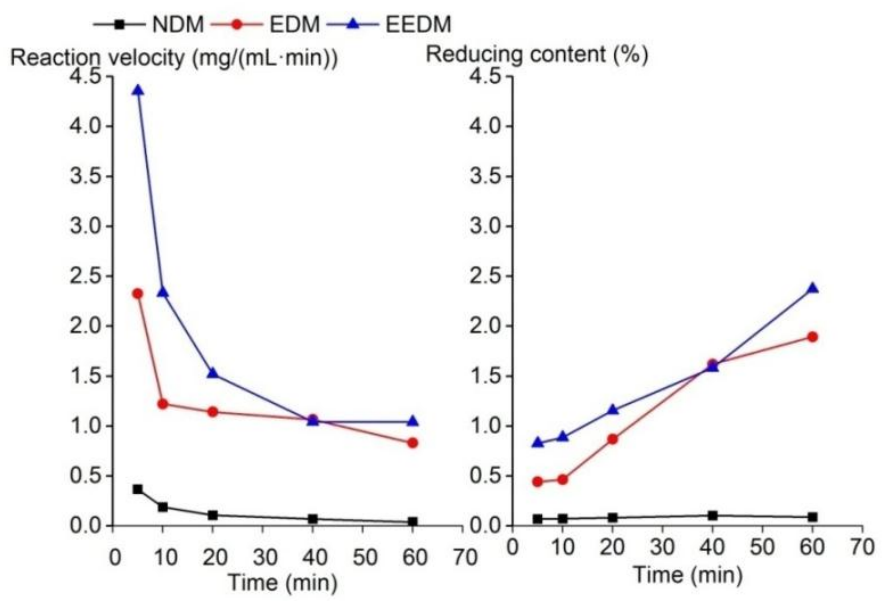

Figure 5. The effect of time on the reaction rate

\section{Conclusion}

These results show that the degree of hydrolysis and reaction rate of EEDM was higher than EDM and NDM. When the substrate $\mathrm{pH}$ was 5.0 , the temperature was $50^{\circ} \mathrm{C}$ and the reaction time was 5 minutes, the higher the concentration of substrate and enzyme present, the faster the reaction rate was. The Vmax and Km of NDM were 0.0845 and 0.0032 , respectively; the Vmax and Km of EDM were 0.6251 and 0.0167 , respectively and the Vmax and $\mathrm{Km}$ of EEDM were 1.1897 and 0.0240, respectively. Enzymatic kinetics of enzymatically extruded degerminated maize with glucamylase followed the basic rules of the Michaelis-Menten equation, which can be used to perform data fitting.

\section{Acknowledgements}

This work was supported by the Natural Science Foundation of China (31471676) and the Higher Education superior discipline team training program of Shandong Province. The authors wish to thank Wang Lina, Chang Weiwei, Wang Xiaowen, Wang Yongzai and Sun Fazhe for help in instrument operation and pictures processing.

\section{References}

Baks, T., Fhj, K., Aem, J., \& Boom, R. M. (2008).Towards an optimal process for gelatinisation and hydrolysis of highly concentrated starch-water mixtures with alpha-amylase from B. licheniformis.Journal of Cereal Science, 47, 214-225. https://doi.org/10.1016/j.jcs.2007.03.011

Baks, T., Janssen, A. E. M., \& Boom, R. M. (2006a).The effect of carbohydrates on $\alpha$-amylase activity measurements.Enzyme \& Microbial Technology, 39, 114-119. https://doi.org/10.1016/j.enzmictec.2005.10.005

Baks, T., Janssen, A. E. M., \& Boom, R. M. (2006b).A kinetic model to explain the maximum in $\alpha$-amylase activity measurements in the presence of small carbohydrates.Biotechnology and Bioengineering, 94, 431-40.https://doi.org/10.1002/bit.20779

BP, E., W, M., AM, v. O., KT, L., G, L., H, S., BJ, C., SC, K., \& XS, X. (2006). Ever-fluctuating single enzyme molecules: Michaelis-Menten equation revisited. Nature Chemical Biology, 2, 87-94. https://doi.org/10.1038/nchembio759

Han, Y. (2009). Study on the Use of Degerminated Maize to Produce Superdry Base Wine. Liquor-Making Science \& Technology, 4, 65-67.

Cao, Y. F., Shuang-Shuang, Y. U., Zhang, D. L., Chen, S. F., Hong-Jun, L. I., \& Cheng-Ye, M. A. (2017). Study on starch change of degermed corn in enzymatic extrusion process. Science \& Technology of Food Industry, 38(12), 118-122. https://doi:10.13386 /j.issn1002-0306.2017.12.022

Gularte, M. A., \&Rosell, C. M. (2011).Physicochemical properties and enzymatic hydrolysis of different starches in the presence of hydrocolloids.Carbohydrate Polymers, 85(1), 237-244. https://doi.org/10.1016/j.carbpol.2011.02.025

Jukić, D., Sabo, K., \&Scitovski, R. (2007). Total least squares fitting michaelis-menten enzyme kinetic model function. Journal of Computational \& Applied Mathematics, 201(1), 230-246. 
https://doi.org/10.1016/j.cam.2006.02.017

Morales, P., Cebadera-Miranda, L., Cámara, R. M., Reis, F. S., Barros, L., Berrios, J. D. J., Ferreira, I. C. F. R.,\&Cámara, M. (2015). Lentil flour formulations to develop new snack-type products by extrusion processing: Phytochemicals and antioxidant capacity. Journal of Functional Foods, 19, 537-544. https://doi.org/10.1016/j.jff.2015.09.044

Polakovič, M., \&Bryjak, J. (2004). Modelling of potato starch saccharification by an Aspergillusnigerglucoamylase. Biochemical Engineering Journal,18, 57-63. https://doi.org/10.1016/S1369-703X(03)00164-5

Raphaelides, S. N., Dimitreli, G., Exarhopoulos, S., Mintzas, D., \&Lykidou, A. (2012).Effect of processing conditions on the physicochemical and structural characteristics of pregelatinised starch-fatty acid-glycerol extrudates.Carbohydrate Polymers, 88, 282-289. https://doi.org/10.1016/j.carbpol.2011.12.003

Román, L., Dura, Á.,Martínez, M. M., Rosell, C. M., \&Gómez, M. (2016). Combination of extrusion and cyclodextringlucanotransferase treatment to modify wheat flours functionality. Food Chemistry, 199, 287-295. https://doi.org/10.1016/j.foodchem.2015.12.040

Shen, D. C., Xi, K. W., \& Ma, C. Y. (2010). Saccharifying Experiment of Degermed Corn with Added Enzyme Extruded at Low Temperature for Production of Corn Syrup. Transactions of the Chinese Society for Agricultural Machinery, 41, 140-145.

Stephen, O. B., \& Wang, Y. J. (2009).Effects of shear and pH on starch phosphates prepared by reactive extrusion as a sustained release agent.Carbohydrate Polymers, 77, 464-471. https://doi.org/10.1016/j.carbpol.2009.01.014

Zhang, B., Dhital, S., Flanagan, B. M., Luckman, P., Halley, P. J., \& Gidley, M. J. (2015). Extrusion induced low-order starch matrices: Enzymic hydrolysis and structure. Carbohydrate Polymers, 134, 485-496. https://doi.org/10.1016/j.carbpol.2015.07.095

Zhang, G., Shi, Y., Wei, Y., \&Ouyang, S. (2007). Kinetics of buckwheat starch enzymatic hydrolysis with fungala -amylase. NongyeGongchengXuebao/transactions of the Chinese Society of Agricultural Engineering, 23, $42-46$.

Zhao, Y., Yong-Gang, T. U., Guo, J. J., \&Jian-Ke, L. I. (2009).Kinetics of $\beta$-Amylase-catalyzed Hydrolysis of Corn Starch.Food Science, 221, 1043-1053.

\section{Copyrights}

Copyright for this articleis retained by the author(s), with first publication rights granted to the journal.

This is an open-access article distributed under the terms and conditions of the CreativeCommons Attribution license (http://creativecommons.org/licenses/by/4.0/). 